\section{References}

Anshari, G., Kershaw, AP. and van der Kaars, S., 2001: A Late Pleistocene and Holocene pollen and charcoal record from peat swamp forest, Lake Sentarum Wildlife Reserve, West Kalimantan, Indonesia, Palaeogeography, Palaeodlimatology, Palaeoecology, 171 213-228

Page, S.E., Siegert, F., Rieley, J.0., Boehm, H.-D.V., Jaya, A. and Limin, S., 2002: The amount of carbon released from peat and forest fires in Indonesia during 1997, Nature, 420: 61-65.
Page, S.E., Wüst, R.A.J., Weiss, D., Rieley, J.0., Shotyk, W. and Limin, S.H 2004: A record of Late Pleistocene and Holocene carbon accumulation and climate change from an equatorial peat bog (Kalimantan, Indonesia): implications for past, present and future carbon dynamics, Journal of Quaternary Science, 19: 625-635.

Page, S.E., Rieley, J.0. and Wüst, R., 2006: Lowland tropical peatlands of Southeast Asia. In: Martini, P., Martinez-Cortizas, A. and Chesworth, W. (Eds) Peatlands: basin evolution and depository of records on global environmental and climatic changes, Elsevier, Amsterdam (Developments in Earth Surface Processes series). pp. $145-172$
Wüst, R.A.J. and Bustin, R.M., 2004: Late Pleistocene and Holocene development of the interior peat-accumulating basin of tropica Tasek Bera, Peninsular Malaysia, Palaeogeography, Palaeoclimatology, Palaeoecology, 211: 241-270.

For full references please consult:

http://www.pages-igbp.org/products/newsletters/ref2010_1.htm

\title{
Inception, history and development of peatlands in the
}

\section{Amazon Basin}

Outı Lähteenoja ${ }^{1}$ and Katherine H. Roucoux ${ }^{2}$

'Department of Biology, University of Turku, Finland; outi.lahteenoja@utu.fi

${ }^{2}$ School of Geography, University of Leeds, UK

The existence of peatlands in the Amazonian lowlands has only recently been confirmed, owing to the remoteness of the area. These peatlands are important for regional carbon cycling and habitat diversity, and represent valuable potential resources for paleoecological research.

\section{The Amazon's floodplain peatlands}

Amazonia, the world's largest continuous area of humid tropical lowland rainforest, is famous for its dense river network, large seasonal variations in water level (on average $10 \mathrm{~m}$ at Manaus, Brazil), and extensive floodplains and wetlands covered by Mauritia palms, floodplain forest or savanna-like vegetation (Irmler, 1977; Junk, 1983; Junk and Piedade, 2005; Keddy et al., 2009). Despite the great extent of wetlands within the Amazon Basin, the existence of tropical peatlands has rarely been considered (but see Suszczynski, 1984; Schulman et al., 1999; Ruokolainen et al., 2001; Guzmán Castillo, 2007). Two studies carried out recently in Peruvian lowland Amazonia (Loreto region, Fig. 1) by members of the Amazon Research Team of the University of Turku (Finland) reveal that peat deposits, up to $6 \mathrm{~m}$ thick, are widespread on floodplain wetlands of the Western Amazon Basin (Lähteenoja et al., 2009a, 2009b). Sixteen of seventeen studied wetland sites contained some kind of peat deposit. According to the very rough estimate of Schulman et al. (1999) based on local land-cover maps, satellite images, grey literature and sporadic field observations, Amazonian peatlands may cover up to $150000 \mathrm{~km}^{2}$, an area equivalent to half of Finland, and about $75 \%$ of the area covered by the better-known tropical peatlands of Indonesia (Rieley and Page, 2005; Page et al., this issue).

\section{History and development}

Since their late Holocene inception, the peatlands identified in Peruvian Amazonia have accumulated peat and carbon at relatively high rates $(0.94-4.88 \mathrm{~mm}$ per year, and $26-195 \mathrm{~g} \mathrm{C} \mathrm{m}^{-2}$ per year, respectively)

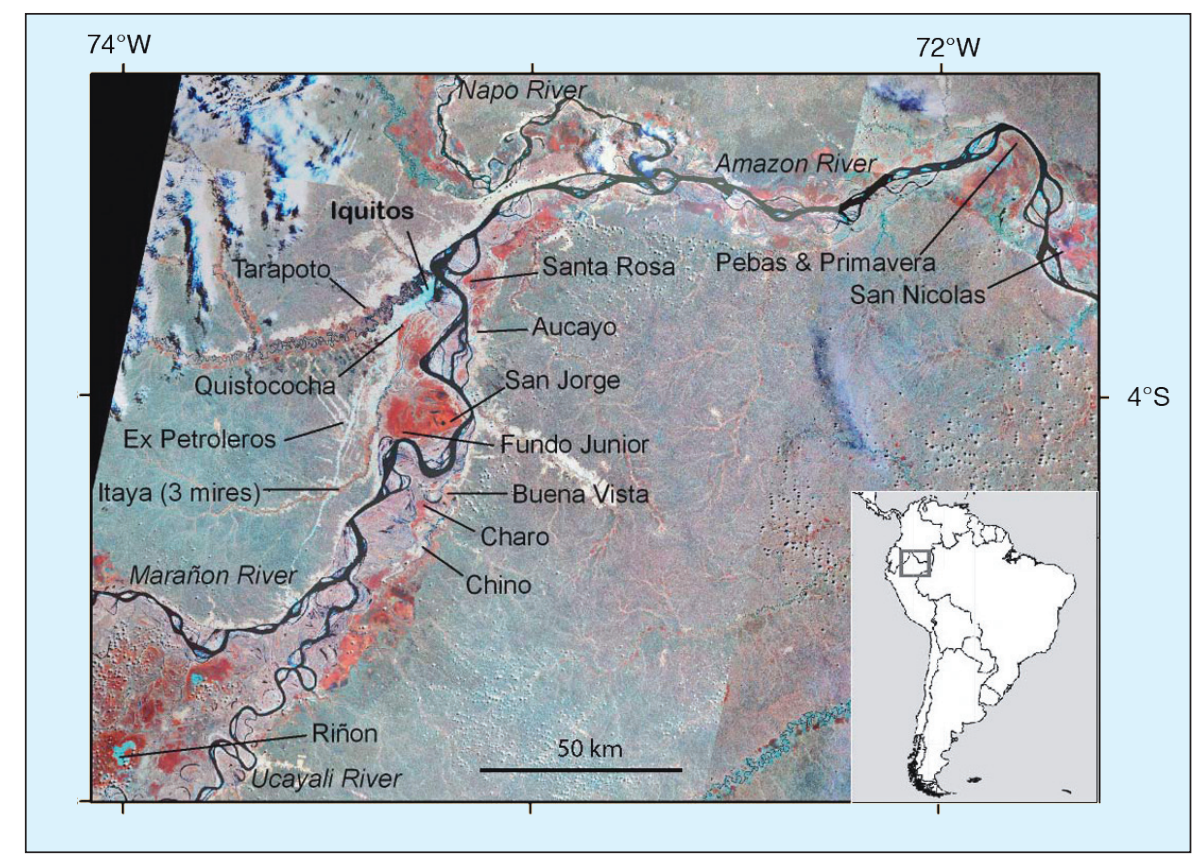

Figure 1: The location of the study sites (from Lähteenoja et al., 2009b, Fig. 1). The map is a mosaic of histogramequalized Landsat TM satellite images (WWw.glcf.umiacs.umd.edu/). Palm swamps and forested wetlands havea reddish tone, more or less treeless open areas (like the open peatland Riñón) are blue-green, and other floodplain forests are pinkish to white.

(Fig. 2) and therefore constitute a strong carbon sink (Lähteenoja et al., 2009b). These accumulation rates are comparable to those of the Indonesian tropical peatlands (Page et al., 2004) and are higher than those of the boreal peatlands (Tolonen and Turunen, 1996).

The basal ages of five dated peat deposits varied from $0.588 \mathrm{cal} \mathrm{ka} \mathrm{BP}$ (at 164 $\mathrm{cm}$ ) to $2.945 \mathrm{cal} \mathrm{ka} \mathrm{BP} \mathrm{(at} 565 \mathrm{~cm}$ ) (Lähteenoja et al., 2009b), which are considerably younger than basal ages determined in peatlands in many other regions of the world (cf., Korhola et al., 2010). There are several possible reasons for this. A paleoecological study of lake sediments in Peruvian Amazonia suggests that the dry conditions of the middle Holocene were followed by a period of increasingly wet conditions beginning some time between 4.2 and 2.54 cal ka BP (Bush et al., 2007). Although our oldest peat initiation dates coincide broadly with the onset of this wet interval, some of the peat deposits have much younger basal ages (Lähteenoja et al., 2009b), indicating that peat formation was not determined purely by climate. Peat initiation may be controlled by the dynamic lateral migration of western Amazonian rivers, characterized by meandering and avulsion (Kalliola et al., 1992; Neller et al., 1992; Pärssinen et al., 1996), which have the potential to erode and bury peat deposits. Peat accumulation probably began when an area with waterlogged conditions was isolated from the immediate destructive influence of rivers. Consequently, the Western Amazon Basin 
may be too dynamic to allow very old peat deposits to form (Lähteenoja et al., 2009b), compared with, for example, those found in the more geologically stable Indonesian tropical lowlands (Page et al., this issue). This reasoning is supported by the presence of several buried peat deposits observed under the mineral subsoil of the peatlands (Lähteenoja et al., 2009b). Older peat deposits might well be found in geologically more stable peripheral areas of the floodplains close to the non-flooded terra firme.

According to peat nutrient analyses and topographic measurements, some of the thickest, oldest and most stable peatlands have attained ombrotrophic (rain fed) conditions, despite their location in the middle of a floodplain environment (Lähteenoja et al., 2009a). The surface of these peatlands has risen above the maximum level of river floods because of their thick peat layer and convex topography (Fig. 2). This change of conditions, from a groundwater-fed system to a rain fed one, affects the ecosystem properties in a drastic way, and, consequently, the variation of ombrotrophic bogs and minerotrophic swamps in the Amazonian lowlands contributes to the regional ecosystem diversity (Fig. 3; Lähteenoja et al., 2009a).

\section{Record of paleoclimate and vegetation dynamics}

The existence of peat deposits (especially ombrotrophic ones) within the Amazon Basin potentially offers an excellent resource for studies of Holocene climate variability, paleohydrology and rainforest vegetation dynamics in the Amazonian lowlands, providing histories extending to the time of peat initiation (cf., Frost and Miller, 1987; Ledru, 2001; Hoorn, 2006). In a new project, due to begin in summer 2010, we will apply pollen, charcoal and sedimentological analyses to three of the peat sequences identified by Lähteenoja et al. (2009b) in order to reconstruct changes in forest composition over the past $3 \mathrm{ka}$, focusing in most detail on the last $1 \mathrm{ka}$, the interval of most direct relevance to current ecological trends. Knowledge of tropical forest history on this timescale is crucial to the interpretation and understanding of recent ecological changes taking place in the forest (Malhi et al., 2002). For example, studies of a network of forest plots across Amazonia (Malhi et al., 2002) show that rates of tree mortality and recruitment (Phillips et al., 2004), growth rates (Lewis et al., 2004) and overall forest biomass (Baker et al., 2004) have increased over the past three decades. Understanding the mechanisms

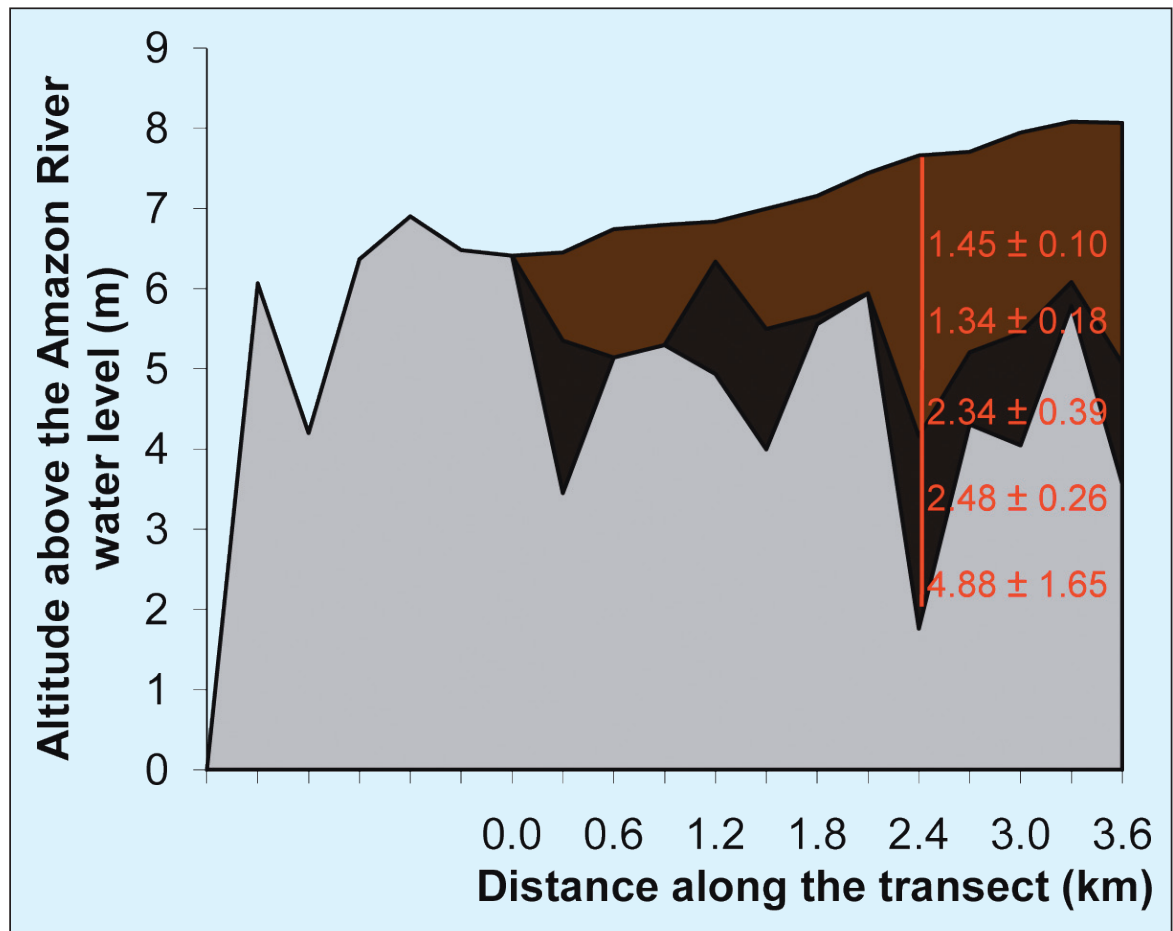

Figure 2: Peat profile and accumulation rates from the San Jorge ombrotrophic bog (Loreto region, Peru). Brown = peat, dark brown = clayey peat, gray = clay. Redrawn from Lähteenoja et al., 2009a). The core location and peat accumulation rates ( $\mathrm{mm} / \mathrm{a}$ ) are shown in red (from Lähteenoja et al., 2009b). behind these changes is important for predicting their consequences for forest biodiversity and for the role of forests in the global carbon cycle (Cox et al., 2008). One possible explanation is that forests are recovering from disturbance events prior to the start of monitoring (Wright, 2005). We intend to test this hypothesis by applying paleoecological techniques to the newly discovered peat sequences. They are ideal for the purpose because: 1) currently no detailed, high resolution records in this region; 2 ) the peat accumulated rapidly so should yield pollen records with decadal scale temporal resolution; and 3) they are located in a region where forest ecology has been monitored in permanent census plots for the past three decades (RAINFOR project: Malhi et al., 2002). The new records will greatly improve our understanding of the mechanisms driving they record an interval for which there are

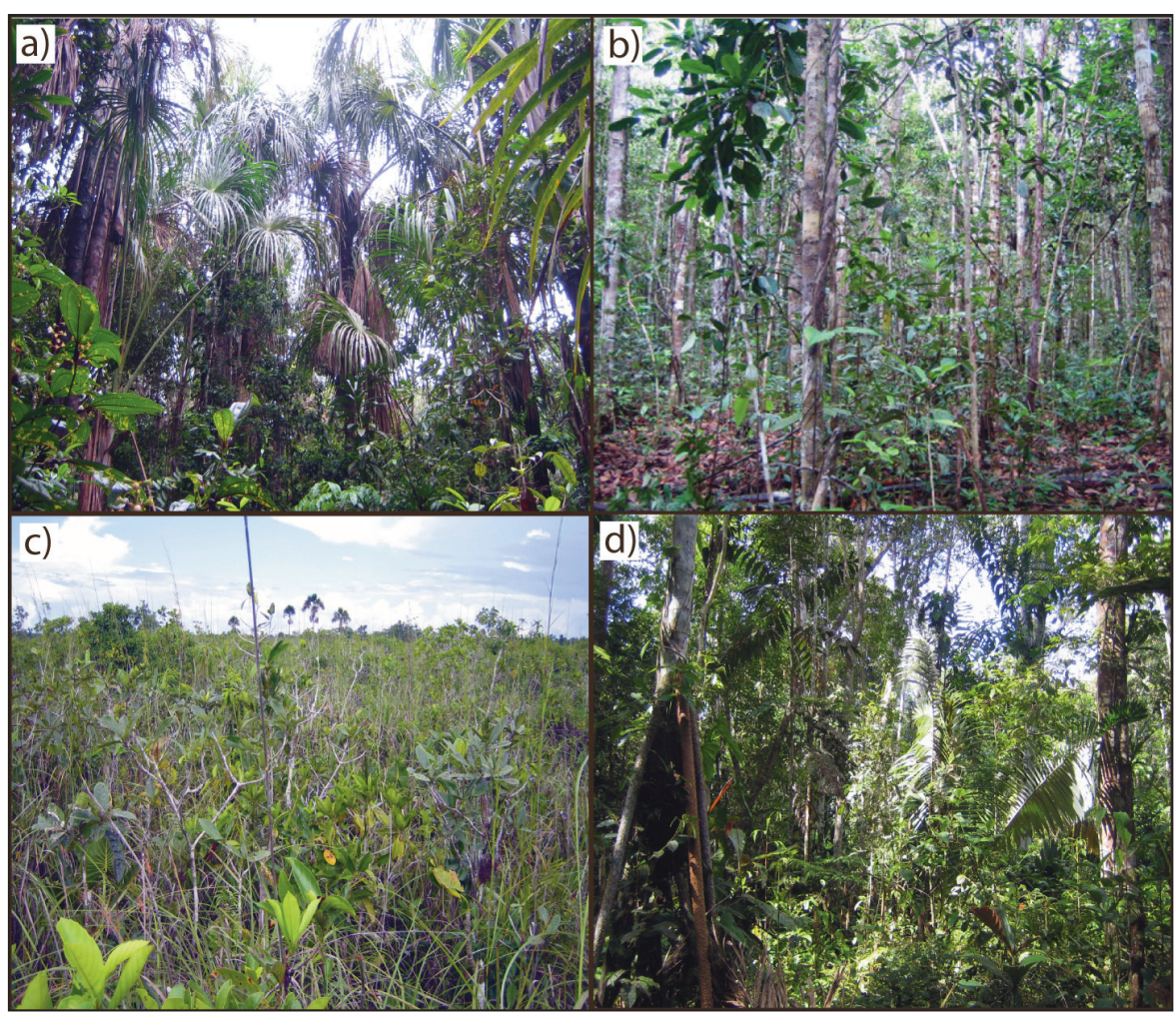

Figure 3: Four of the peatland sites indentified by Lähteenoja et al. (2009a, 2009b) in Peruvian Amazonia (Loreto): a Mauritia flexuosa peat swamp (Quistococha), b) forested peatland (San Jorge), c) savanna-like peatland (Riñón), d) forested peatland (Fundo Junior). 
current changes in tropical forest ecology and the sensitivity of these forests to future climatic change.

In contrast to the Southeast Asian tropical peatlands, these Amazonian peatland sites do not appear to be currently directly affected by anthropogenic actions. Nevertheless, climate change, deforestation, large-scale land-use projects (such as river damming, road construction and development of oil palm plantations) and extensive gas and oil exploration (Malhi et al., 2008) represent an indirect threat to the peatlands insofar as they contribute to drying of the regional climate. Consequently, there is an urgent need to investigate further, and conserve, these littleknown Amazonian ecosystems.

\section{References}

Guzmán Castillo, W., 2007: Valor económico del manejo sostenible de los ecosistemas de aguaje (Mauritia flexuosa). In: Feyen, J., et al. (Eds), International Congress on Development, Environment and Natural Resources: Multi-level and Multi-scale Sustainability, Volume III, Publication of the Universidad Mayor San Simón, Cochabamba, Bolivia, 1513-1521.
Lähteenoja, 0., Ruokolainen, K., Schulman, L. and Alvarez, J., 2009a: Amazonian floodplains harbour minerotrophic and ombrotrophic peatlands, Catena, 79: 140-145.

Lähteenoja, 0., Ruokolainen, K., Schulman, L. and Oinonen, M., 2009b: Amazonian peatlands: an ignored ( sink and potential source, Global Change Biology, 15: 2311-2320.

Ruokolainen, K., Schulman, L. and Tuomisto, H., 2001: On Amazonian peatlands, International Mire Conservation Group Newsletter, 2001(4): 8-10.

Schulman, L., Ruokolainen, K. and Tuomisto, H., 1999: Parameters for global ecosystem models, Nature, 399: 535-536.

For full references please consult:

http://www.pages-igbp.org/products/newsletters/ref2010_1.html

\section{Peatland exchanges of $\mathrm{CO}_{2}$ and $\mathrm{CH}_{4}$ : The importance of presence or absence of permafrost}

Torben R. Christensen ${ }^{1}$, M. Mastepanov ${ }^{1}$, M. Johansson ${ }^{1}$ and D. Charman ${ }^{2}$

'Department of Earth and Ecosystem Science, Lund University, Sweden; torben.christensen@nateko.lu.se 2School of Geography, University of Exeter, UK

\section{The presence of permafrost is shown to have dramatic impacts on land-atmosphere exchanges of key greenhouse gases.}

\section{Permafrost and the carbon cycle}

Permafrost, soil that stays frozen for two or more years in a row, is a hot topic that has attracted a lot of attention in both the scientific and popular literature in recent years. Permafrost underlies 25\% of the land areas in the Northern Hemisphere including substantial areas with peatlands. With a warming climate that is particularly pronounced at high northern latitudes, where most permafrost is present, many questions have been raised regarding what may happen to peatlands and their functioning when permafrost thaws. In areas with infrastructure, such as towns in northern Siberia, or oil and gas pipelines through areas underlain by permafrost, the thawing represents a serious and possibly very expensive issue. Thawing permafrost may, however, have global implications through changes in natural ecosystem greenhouse-gas emissions.

Permafrost areas in the circumpolar North are estimated to hold more than $1600 \mathrm{Pg}$ of organic carbon (C) including almost $300 \mathrm{Pg}$ in the form of peat (McGuire et al., 2009; Tarnocai et al., 2009) most of which has accumulated since the last glacial maximum. In terms of atmospheric exchange of carbon, in the form of $\mathrm{CO}_{2}$ and $\mathrm{CH}_{4}$, the potential for additional releases are probably greater from these areas than anywhere else in the world. While the potential release from the huge stocks of carbon is significant, the actual data and year-round monitoring of atmospheric exchanges remain rare, and continuous flux measurements of $\mathrm{CO}_{2}$ are limited to a handful of sites. Continuous monitor-

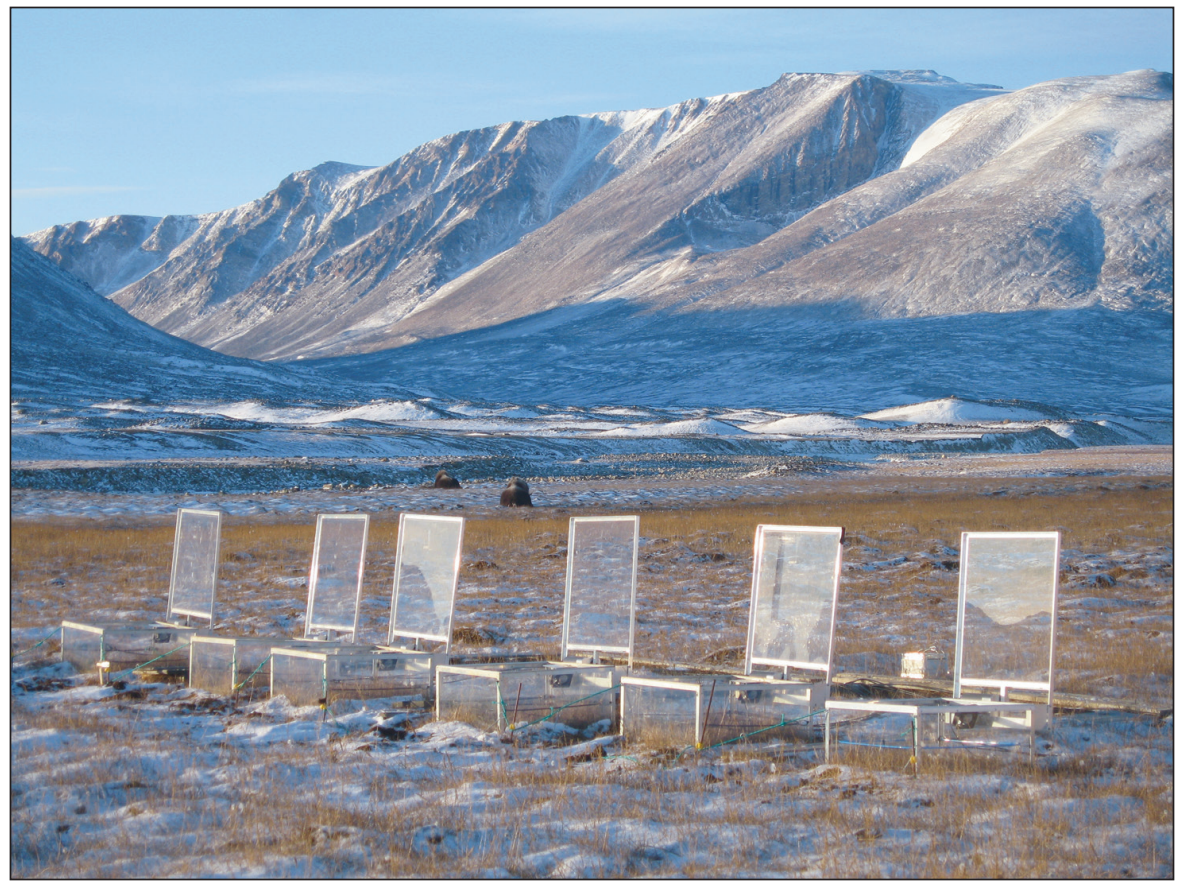

Figure 1: The Zackenberg valley in NE Greenland, an area underlain by continuous permafrost. The automatic chambers were used for the studies of methane emission dynamics during freeze-in (Mastepanov et al., 2008). Local inhabitants, the muskoxen, are present in the background. Photo by C. Sigsgaard, from Christensen et al., 2009 , reprinted with permission.

ing of $\mathrm{CH}_{4}$ fluxes is even rarer; the number of operational sites is less than five. Our empirically based understanding of what permafrost does to the dynamics and interannual variability in atmospheric (and dissolved run-off) fluxes of organic carbon is therefore still very poor. The longer-term dynamics on decadal to centennial timescales are even less well understood.

\section{Carbon dynamics}

Basic features of how ecosystems are functioning with and without permafrost have recently been discovered. At a central
Alaskan site, Schuur et al. (2009) demonstrated that permafrost thawing is accompanied by respiration of previously frozen, ancient organic carbon. In Siberian thaw lakes, methane has been observed forming from recently thawed Pleistocene organic deposits (Walter et al., 2007).

The interannual and across-site variability of $\mathrm{CO}_{2}$ exchange in continuous permafrost ecosystems are driven primarily by growing-season dynamics and moisture conditions. Several studies have shown that growing-season rates of $\mathrm{CO}_{2}$ uptake by these ecosystems is closely re- 


\section{O. Lähteenoja and K.H. Roucoux}

Baker, T.R., et al., 2004: Variation in wood density determines spatial patterns in Amazonian forest biomass, Global Change Biology, 10: 545-562.

Bush, M.B., Silman, M.R. and Listopad, M.C.S., 2007: A regional study of Holocene climate change and human occupation in Peruvian Amazonia, Journal of Biogeography, 34(8): 1342-1356.

Cox, P.M., Harris, P.P., Huntingford, C., Betts, R.A., Collins, M., Jones, C.D., Jupp, T.E., Marengo, J.A. and Nobre, C.A., 2008: Increasing risk of Amazonian drought due to decreasing aerosol pollution, Nature, 453: 212-215.

Frost, I.G. and Miller, M.C., 1987: Late Holocene flooding in the Ecuadorian rainforest, Freshwater Biology 18(3): 443-453.

Guzmán Castillo, W., 2007: Valor económico del manejo sostenible de los ecosistemas de aguaje (Mauritia flexuosa). In: Feyen, J., et al. (Eds), International Congress on Development, Environment and Natural Resources: Multi-level and Multi-scale Sustainability, Volume III, Publication of the Universidad Mayor San Simón, Cochabamba, Bolivia, 1513-1521.

Hoorn, C., 2006: Mangrove Forests and Marine Incursions in Neogene Amazonia (Lower Apaporis River, Colombia), Palaios, 21: 197-209.

Irmler, U., 1977: Inundation - forest types in the vicinity of Manaus, Biogeographica 8: 1729.

Junk, W.J., 1983: Ecology of swamps on the middle Amazon. In: Gore, A.J.P. (Ed), Mires: swamp, bog, fen and moor, regional studies; ecosystems of the World 4B, Elsevier, Amsterdam, The Netherlands, 269-294.

Junk, W.J. and Piedade, M.T.F., 2005: The Amazon River basin. In: Fraser, L.H., et al. (Eds), The World's Largest Wetlands: Ecology and Conservation, Cambridge University Press, 63-117.

Kalliola, R., Salo, J., Puhakka, M., Rajasilta, M., Häme, T., Neller, R.J., Räsänen, M.E. and Danjoy, Arias W.A., 1992: Upper Amazon channel migration: Implications for vegetation perturbance and succession using bitemporal Landsat MSS images, Naturwissenschaften, 79: 75-79.

Keddy, P.A., Fraser, L.H., Solomeshch, A.I., Junk, W.J., Campbell, D.R., Arroyo, M.T.K. and Alho, C.J.R., 2009: Wet and Wonderful: The World's Largest Wetlands Are Conservation Priorities, BioScience, 59(1): 39-51.

Korhola, A., Ruppel, M., Seppä, H., Väliranta, M., Virtanen, T. and Weckström, J., in press: The importance of northern peatland expansion to the late-Holocene rise of atmospheric methane, Quaternary Science Reviews, 29(5-6): 611-617.

Lähteenoja, O., Ruokolainen, K., Schulman, L. and Alvarez, J., 2009a: Amazonian floodplains harbour minerotrophic and ombrotrophic peatlands, Catena, 79: 140-145.

Lähteenoja, O., Ruokolainen, K., Schulman, L. and Oinonen, M., 2009b: Amazonian peatlands: an ignored C sink and potential source, Global Change Biology, 15: 23112320.

Ledru, M.P., 2001: Late Holocene rainforest disturbance in French Guiana, Review of Palaeobotany and Palynology, 115: 161-170.

Lewis, S.L., et al., 2004: Are global change agents causing widespread changes in tropical forest dynamics? Evidence from 50 South American long-term monitoring plots, Philosophical Transactions of the Royal Society of London, Series B, 359: 421-436.

Malhi, Y., et al., 2002: An international network to understand the biomass and dynamics of Amazonian forests (RAINFOR), Journal of Vegetation Science, 13: 439-450.

Malhi, Y., Roberts, J.T., Betts, R.A., Killeen, T.J., Li, W. and Noble, C.A., 2008: Climate Change, Deforestation and the Fate of the Amazon, Science, 319: 169-172.

Neller, R.J., Salo, J.S. and Räsänen, M.E., 1992: On the formation of blocked valley lakes by channel avulsion in Upper Amazon foreland basins, Zeitschrift für Geomorphologie, 36(4): 401-411.

Page, S.E., Wüst, R.A.J., Weiss, D., Rieley, J.O., Shotyk, W. and Limin, S.H., 2004: A record of Late Pleistocene and Holocene carbon accumulation and climate change from an 
equatorial peat bog (Kalimantan, Indonesia): implications for past, present and future carbon dynamics, Journal of Quaternary Science, 19: 625-635.

Page, S.E., Wüst R.A.J. and Banks, C., 2010: Past and present carbon accumulation and loss in Southeast Asian peatlands, PAGES news, 18(1).

Pärssinen, M.H., Salo, J.S. and Räsänen, M.E., 1996: River floodplain relocations and the abandonment of aborigine settlements in the Upper Amazon Basin: a historical case study of San Miguel de Cunibos at the Middle Ucayali River, Geoarchaeology: An International Journal, 11(4): 345-359.

Phillips, O., Baker, T.R., Arroyo, L., Higuchi, N., Killeen, T., Laurance, W.F., Lewis, S.L., Lloyd, J., Malhi, Y. and Monteagudo, A., 2004: Pattern and process in Amazon tree turnover, 1976-2001, Philosophical Transactions of the Royal Society of London, Series $B$, 359: 381-407.

Rieley, J.O. and Page, S.E., 2005: Wise use of tropical peatlands: Focus on Southeast Asia. Alterra - Wageningen University and Research Center and the EU INCO-STRAPEAT and RESTORPEAT Partnerships: 168.

Ruokolainen, K., Schulman, L. and Tuomisto, H., 2001: On Amazonian peatlands, International Mire Conservation Group Newsletter, 2001(4): 8-10.

Schulman, L., Ruokolainen, K. and Tuomisto, H., 1999: Parameters for global ecosystem models, Nature, 399: 535-536.

Suszczynski, E., 1984: The peat resources of Brazil. Proceedings of the 7th International Peat Congress, Dublin 1: 468-492.

Tolonen, K. and Turunen, J., 1996: Accumulation rates of carbon in mires in Finland and implications for climate change, The Holocene, 6(2): 171-178.

Wright, S.J., 2005: Tropical forests in a changing environment, Trends in Ecology \& Evolution, 20(10): 553-560. 